\title{
MEMBANGUN KETERAMPILAN BAHASA SEBAGAI POTENSI UTAMA KECERDASAN INTELEKTUAL BAGI SISWA SD KELAS RENDAH
}

\author{
Isnaniah \\ UPTD SD Negeri 1 Liang Anggang \\ email: isnaniah888@gmail.com
}

\begin{abstract}
ABSTRAK
Penelitian teoritis ini akan mejabarkan beberapa bagian dari keterampilan berbahasa yang menjadi potensi mengembangkan kecerdasan siswa sebagai bagian dari proses pembelajaran Bahasa Indonesia.Secara efesien pembentukan kecerdasan intelektual dibangun sejak dini agar dapat berkembang secara optimal seiring tumbuh kembangnya seorang individu Kecerdasan intelektual merupakan kemampuan potensi manusia dalam mempelajari suatu melalui alat berpikirnya yang tampak pada kekuatan verbal dan logikanya.Jenis penelitian ini adalah kualitatif deskriptif yang berusaha menguraikan dan menggabrakan secara efesien mengenai suatu permasalahan.

Pendekatan penelitian ini adalah psikolinguistik yang berusaha mengungkapkan hubungan bahasa dengan kecerdasan siswa SD kelas rendah. Sumber data penelitian ini adalah pada Buku Tematik Terpadu Kurikulum 2013 kelas 2 Tema 6 Merawat Hewan dan Tumbuhan. Hasil penelitian ini mengungkapkan metode dan teknik yang dapat dilakukan guru pada siswa SD kelas 2 dalam mengembangkan kecerdasan lingiuistik salah satunya dalam aspek berbicara dapat dilakukan dengan kegiatan, 1) membaca puisi, 2) bercerita, 3) bernyanyi, dan 4) menjawab pertanyaan.
\end{abstract}

Kata Kunci: keterampilan bahasa, kecerdasan intelektual, kelas rendah

\section{PENDAHULUAN}

Kecerdasan intelektual dibangun melalui berbagai faktor, diantaranya keturunan genetik dan proses pembelajaran. Kecerdasan yang diperoleh melalui keturunan genetik tetap harus dikembangkan dan diasah melalui proses pendidikan dan pembelajaran baik secara formal maupun informal. Secara efesien pembentukan kecerdasan intelektual dibangun sejak dini agar dapat berkembang secara optimal seiring tumbuh kembangnya seorang individu. Kecerdasan terdiri atas beberapa bagian mulai dari verbal, visual, kinstetik dan psikomotorik. Kompetensi dasar kecerdasan verbal telah dimiliki manusia sejak lahir, namun harus terus dikembangkan dan dilatih agar keterampilan-keterampilan berbahasa produktif secara optimal. Keterampilan berbahasa meliputi keterampilan reseptif (mendengarkan dan membaca) dan keterampilan produktif (menulis dan berbicara.

Pada siswa tingkat sekolah dasar merupakan usia emas bagi anak untuk mengembangkan potensi kecerdasan intelektual. Keterampilan dasar yang diajarkan pada siswa SD ialah membaca 
dan bebicara. Yumnah (2016: 31), kecerdasan intelektual merupakan kemampuan potensi manusia dalam mempelajari suatu melalui alat berpikirnya yang tampak pada kekuatan verbal dan logikanya. Setiap siswa diajarkan mengenal huruf, membaca suku kata, kata dan membaca kalimat sederhana. Pada Keterampilan berbiacara siswa diajarkan untuk saling berkomunikasi dengan sopan dan baik kepada guru atau sesame teman.

Keterampilan berbiacara dapat menjadi salah satu tolak ukur kecerdasan intelektual siswa sekolah dasar. Cahyo (2013: 199), menyatakan bahwa pembelajaran bahasa Indonesia bertujuan membekali siswa seperangkat pengetahuan meliputi pemahaman, keterampilan berpikir, kematangan emosional, dan kematangan sosial. Pembelajaran bahasa Indonesia di sekolah belum mengarah pada fungsi pragmatic bahasa. Konsep kecerdasan bahasa atau linguistik merupakan kemampuan mengolah kata dalam keterampilan berbicara yang mempengaruhi kecerdasan seorang anak (Sujiono 2012: 185; Sinapati, Syamsuddin, dan Barasandji: 92). Pada akhirnyaa salah satu tolak ukur kecerdasan siswa akan tampak melalui kegiatan berbicara baik dalam proses pembelajaran maupun tidak.

Proses pembelajaran di sekolah secara kompleks membantu mengembangkan mental dan kognisi peserta didik. Guru memiliki kontrol utama dalam menentukan dalam pengembangan setiap siswanya dengan perlakuan yang berbeda, melalui keterampilan bicara yang dimiliki siswa. Suyadi (2014: 126), berpendapat bahwa kecerdasan linguistik merepresentasikan olah pikir seseorang. Berdasarkan kegiatan verbal tersebut guru memiliki bayangan sejauh mana pikiran serta pikiran siswanya. Selain itu, Halimah (2016: 122) menjabarkan mengenai manfaat mengembangkan kecerdasan linguistik diantaranya memudahkan siswa berkomunikasi, kemampuan meyakinkan orang lain, memudahkan mengingat atau menghafal informasi, menjelaskan suatu hal, dan mengungkapkan ekspresi jiwa atau pikirannya. Guru disarakan untuk memberikan motivasi dalam mengembangkan keterampilan berbicara siswa dengan cara aktif bertanya pada siswa, aktif bercerita dan mengemukakan hal-hal yang dapat merangsang rasa ingin tahu siswa.

Berdasarkan uraian tersebut, peneliti tertarik mengungkapkan aspek keterampilan berbicara sebagai bagian dari upaya optimalisasi kecerdasan intelektual siswa sekolah dasar kelas rendah. Penelitian teoritis ini akan mejabarkan beberapa bagian dari keterampilan berbahasa yang menjadi potensi mengembangkan kecerdasan siswa sebagai bagian dari proses pembelajaran Bahasa Indonesia. 


\section{METODE}

Jenis penelitian ini adalah kualitatif deskriptif yang berusaha menguraikan dan menggabrakan secara efesien mengenai suatu permasalahan. Pendekatan penelitian ini adalah psikolinguistik yang berusaha mengungkapkan hubungan bahasa dengan kecerdasan siswa SD kelas rendah. Sumber data penelitian ini adalah pada Buku Tematik Terpadu Kurikulum 2013 kelas 2 Tema 6 Merawat Hewan dan Tumbuhan.

Data penelitian ini adalah beberapa tugas atau latihan yang memuat kegiatan dan keterampilan berbicara siswa. Teknik penelitian ini menggunakan studi kepustakaan melalui jurnal, buku atau bahan bacaan lainnya yang berkaitan dengan fokus permasalahan. Teknik analisis data dengan menklasifikasikan data yang berhubungan dengan sub permasalahan, kemudian dilakukan analisis secara efektif untuk mengemukakan pemecahan masalah yang dapat dilakukan guru dalam proses pembelajaran.

\section{HASIL DAN PEMBAHASAN}

Aspek berbicara dalam proses pembelajaran terdiri atas beberapa kegiatan yang terdapat dalam buku tematik, meliputi membaca puisi, bercerita, bernyanyi dan menjawab pertanyaan. Setiap kegiatan tersebut, terus berulang dalam setiap subtema. Dalam buku tematik terdapat sub tema, sementra dalam persemester tema yang diajarkan sebanyak 5 buah. Berdasarkan ilustrasi tersebut, maka aspek-aspek kegiatan berbicara dapat diterapkan untuk masing-masing siswa secara bergiliran. Proses pembelajaran tersebut akan mencapai tujuan utama yaitu kecerdasan linguistik, sementara tujuan lainnya akan terpenuhi seperti menambah semangat belajar dan mengolah proses pembelajaran lebih aktif.

\section{Membaca Puisi}

Pada satuan pendidikan dasar siswa telah diperkenalkan pada kegiatan apresiasi sastra yang merupakan bagian pelajaran bahasa Indonesia. Tujuan kegiatan apresiasi sastra pada sekolah dasar tingkat rendah ialah sebagai pengenalan dan pembiasaan terhadap keberadaan sastra sebagai suatu subjek baru dalam pengetahuan mereka. Soleh (2010: 6), mengemukakan salah satu teknik membaca puisi adalah dengan membawa teks (poetry reading). Berdasarkan hal tersebut,teknik tersebut sesuai dengan kemampuan siswa yang masih dalam tahap esklporasi dan perkembangan. Kegiatan pembelajaran membaca puisi terintegrasi dengan kegiatan membaca yang berjudul 'Ayo Membaca', seperti pada gambar berikut ini. 


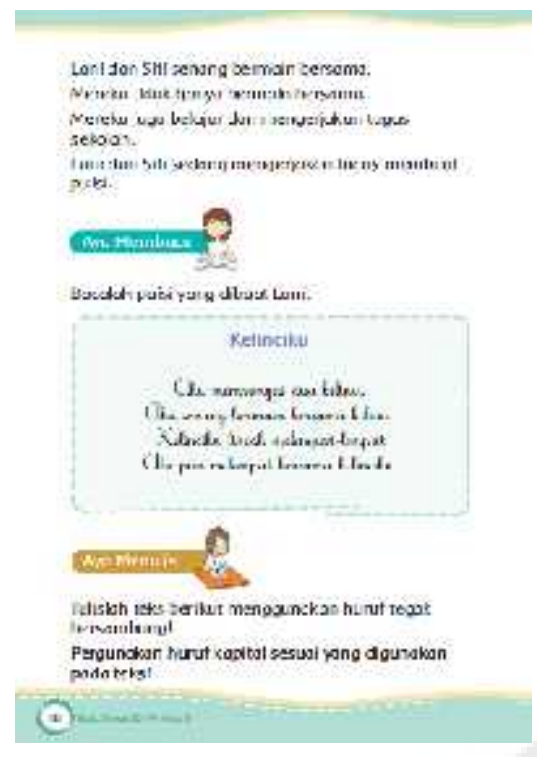

Kegiatan berbicara yang dilakukan dengan membaca puisi dapat mengasah sensitifitas siswa terhadap bahasa dan kreativitas dalam mengungkapkan pikiran dan perasaan. Setyaningsih (2010: 56), menyatakan bahwa ketepatan pengungkapan gagasan, pendapat, perasaan sebaiknya didukung dengan penggunaan bahasa tepat dalam kaidah bahasa yang berlaku. Melalui hal tersebut, kegiatan berbicara yang dipadukan dengan keterampilan membaca puisi diperlukan untuk mengespresikan pemahaman jelas dalam menyampaikan gagasan dan perasaan. Kegiatan membaca puisi ini memerlukan motivasi dan dorongan yang tinggi dari guru, sehingga siswa menjadi lebih percaya diri dan membantu dalam proses linguistik, khususnya dalam kegiatan berbicara.

Menggunakan teknik membaca nyaring dan indah, akan menghasilkan keterampilan berbicara yang indah dan sesuai dengan konteks. Dalam hal ini, peneliaian guru berfokus pada bagaimana kemampuan berbicara yang ditampilkan siswa, dibandingkan mengenai intonasi, irama dan ketepatan keindahan pembacaan puisi. Siswa dapat melakukannya bergantian setiap minggu sehingga memberikan rasa bangga pada siswa yang telah melakukan dan menambah rasa semangat bagi siswa yang belum mendapatkan giliran.

\section{Bercerita}

Buku Tematik Terpadu Kurikulum 2013 telah dirancang sedemikian rupa yang mencakup serangkaian keterampilan berbahasa sesuai dengan perekembangan siswa sekolah dasar. Salah satunya terdapat kegiatan membaca sesuai pada gambar 2. Jika guru hanya menggunakan media ini secara pasif, maka siswa hanya akan diarahkan untuk membaca secara individu. Namun, ketika guru mampu mengeksplorasi kemampuan siswa, kegiatan membaca ini dapat dimodifikasi menjadi kegiatan bercerita dengan membacakan teks yang telah disediakan, Seperti pada gambar berikut. 


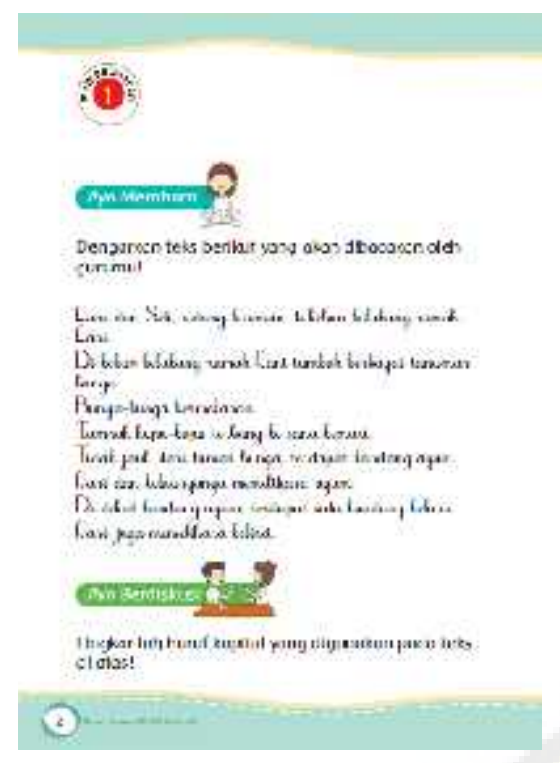

Kegiatan bercerita merupakan keterampilan yang berkaitan dengan kemampuan berpikir tingkat tinggi, namun siswa sekolah dasar kelas rendah dapat dilatih dan dibiasakan bercerita sederhana dengan membaca teks cerita yang telah tersedia. Anggraini (2016: 632) mengungkapkan bahwa bercerita merupakan sarana komunikasi linguistik yang kuat serta menghibur bertujuan berbagi pengalaman dengan intonasi dan pengimajinasian. Walau tampak sederhana, namun terdapat aspek penunjang lain yang akan dikembangkan seperti kepercayaan diri, keberanian, melatih kemampuan membaca dan mengarahkan siswa untuk mahir berbicara.

Pada siswa kelas 2 SD bukanlah hal mudah untuk mengarahan dan memotivasi siswa untuk tampil berani, namun hal tersebut bukanlah hal yang tidak mungkin. Untuk itu, guru kembali harus lebih aktif dan menyenangkan dalam memberikan arahan dan menjadi model utama yang memberikan motivasi. Marlina, Apriliya dan Hamdu (2018: 86), menyatakan bercerita merupakan kegiatan menuturkan atau mengisahkan suatu perbuatan atau kejadian untuk mengukur keterampilan dan pengetahuan siswa yang kontekstual, relevan dan sesuai perkembangan pengalaman siswa. Setelah siswa selesai bercerita, terdapat beberapa aspek pengetahuan dan keterampilan yang akan ditunjukan siswa secara mandiri. Hal ini, secara tidak langsung merupakan kegiatan evaluasi terhadap proses perkembangan peserta didik setiap saat.

Poin utama yang perlu diperhatikan ialah mengembangkan kecerdasan linguistik, karena pada dasarnya usia siswa 7-8 tahun berada dalam masa emas perkembangan yang harus terus digali dan dikembangkan. Kegiatan proses perkembangan tidak melulu terpaku pada akademik, karena kegiatan linguistik mampu menunjang kecerdasan kognitif seorang anak. Prayoga (2012: 122), menyatakan hal serupa bahwa anak usia sekolah dasar menunjukkan kecerdasannya dalam 
melakukan seriasi, mengelompokkan, berminat pada angka dan tulisan, meningkatkan perbendaharaan kata, senang berbicara dan mencari tahu sebab akibat hingga mengembangkan pemahaman terhadap ruang dan waktu.

\section{Bernyanyi}

Kurikulum 2013 saat ini telah dirancang sedemikian rupa dalam sebuah tema yang dekat dan kontekstual dengan kehidupan siswa sehari-hari. Dalam proses pendalaman tema tersebut dilakukan berbagai metode dan teknik pembelajaran yang beragam, sub tema yang digali dalam sebuah tema juga berkembang tidak hanya pada satu mata pelajaran, namun memungkinkan untuk terpadu menjadi beberapa mata pelajaran. Salah satu materi dalam tema ialah kegiatan bernyanyi yang termasuk dalam mata pelajaran seni budaya. Kegiatan bernyanyi secara langsung berkaitan dengan keterampilan berbicara, karena secara keseluruhan mengandalkan kemampuan verbal, Sumaryanto (2005: 36), menyatakan bahwa unsur-unsur musik yaitu irama, melodi, harmoni, ekspresi, dan bentuk atau struktur lagu. Secara tidak langsung, melalui kegiatan bernyanyi akan mengembangkan keterampilan berbahasa atau verbal anak.

Secara umum telah diketahui bahwa siswa SD kelas 2 masih berada dalam masa anak-anak, terkadang guru atau orang tua menganggap mereka seakan-akan dewasa sehingga kegiatan anakanak seperti bernyanyi dan menari dianggap tidak sesuai dengan umur mereka. Padahal pada kenyataanya, jiwa dan mental mereka masih berada dalam umur anak-anak, sehingga masih menyukai kegiatan seperti saat di taman kanak-kanak. Jamalus (1998:46), menyatakan bernyanyi adalah kegiatan menyenangkan bagi anak serta memberikan kepuaasan pengalaman sebagai sarana mengungkapkan perasaan dan pikirannya dengan cara yang kreatif. Berikut materi kegiatan bernyanyi dalam buku kelas 2 tema 6 :

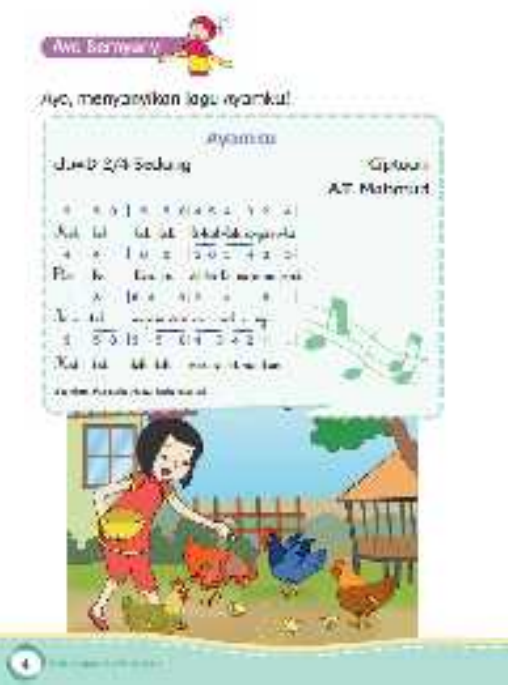


Pada materi di atas, tampak judul kegiatan pembelajaran adalah 'Ayo Bernyanyi'. Judul laguAyamku sesuai dengan tema pembelajaran yaituMerawat Hewan dan Tumbuhan. Pada kegiatan ini dalam praktiknya guru hanya memutarkan audio, sehingga siswa dapat mendengarkan bersamasama. Padahal, dalam hal ini musik menjadi salah satu bagian dalam aspek kebahasaan. Sumaryanto (2005: 36), musik merupakan bahasa emosi yang bersifat emosional yang mengandung makna dan kesan yang mendalam. Berdasarkan hal tersebut, melalui kegiatan bernyanyi sebagai sarana mengungkapkan pikiran dan perasaan dengan tujuan memperoleh pengalaman berekspresi dan berapresiasi yang bersifat keterampilan dasar.

Metode pembelajaran yang dapat dilakukan ialah menggunakan demonstrasi. Sanjaya (2006: 21), mengemukakan metode demonstrasi merupakan pengelolaan pembelajaraan yang memperagakan dan mempertunjukkan suatu proses, situasi, benda atau cara kerja yang sedang dipelajari. Secara teori siswa akan mendapatkan pengalaman belajar yang bermakna jika mereka memperoleh pembelajaran langsung setelah melihat, melakukan dan merasakan. Secara langsung metode demonstrasi dalam proses pembelajaran akan lebih berkesan dan memberikan motivasi kepada siswa (Lahamando, tt: 37). Berdasarkan pembahasan tersebut, maka pembelajaran bernyani dapat dimodifikasi dalam pembelajaran terpadu yang mengandung aspek kebahasaan. Proses pembelajaran menjadi lebih menyenangkan terlebih lagi jika setiap siswa mendapatkan giliran masing-masing di depan kelas untuk mendemonstrasikan secara sederhana, dengan tujuan memandu teman-temannya untuk bernyanyi bersama-sama.

\section{Menjawab Pertanyaan}

Kegiatan menjawab pertanyaan merupakan serangkaikan metode yang dilakukan guru dengan melakukan stimulus terlebih dahulu. Stimulus yang digunaka berupa mengajukan pertanyaan sedemikian rupa agar mampu menggugah respon positif dan antusias dari siswa. (Zuchdi dan Budiasih, 1997: 32) menyatakan bahwa pengembangan keterampilan berbicara di sekolah dasar yakni secara vertikal artinya siswa telah mampu mengungkapkan pesan secara langsung dengan kurang sempurna. Melalui stimulis pertanyaan secara berulang akan mampu mengambangkan keerdasan linguistik siswa yang semakin hari semakin baik dan menuju kea rah sempurna. Seperti gambar tangkapan layar berikut ini dari buku tematik 6 pada sub tema 1 kegiatan 'Ayo Mengamati', sebagai berikut. 


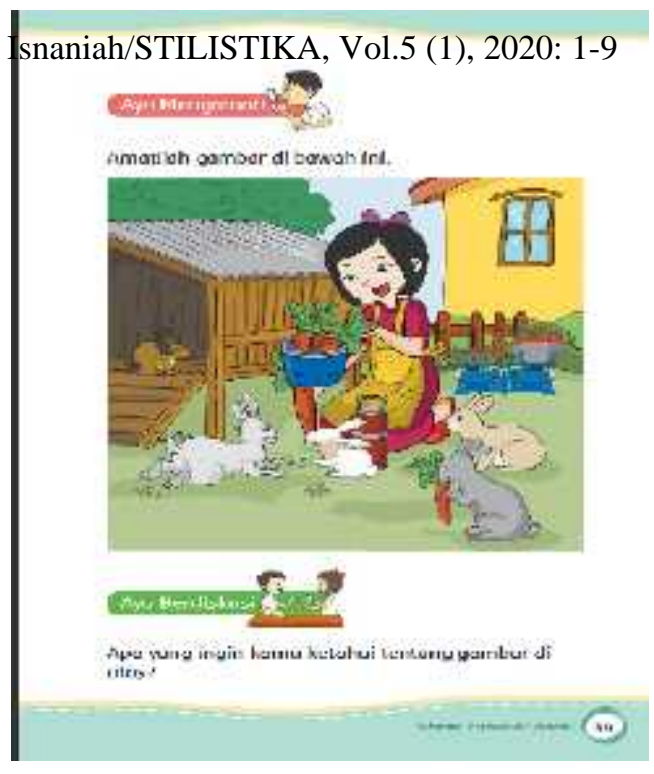

Pada Gambar 4 di atas menunjukkan kegiatan mengamati yang bertujuan menggali pertanyaan siswa yang diolah melalui pengalaman dan pengetahuan dari kegiatan sehari-hari. Pada bagian selanjutnya merupakan kegiatan diskusi dan mengarahkan siswa untuk mampu mengungkapkan perasaan dan pikirannya melalui keterampilan berbicara sesuai dengan konteks gambar dan pertanyaan yang telah dikembangkan oleh guru.

Pada praktik dan kenyataanya guru memang harus lebih aktif berbicara terlebih dahulu untuk memberikan stimulus pada siswa. Kegiatan diskusi dan menjawab pertanyaan merupakan keterampilan berbicara yang lebih kompleks dibandingkan kegiatan sebelumnya karena menuntut adanya pemilihan kata dan penalaran yang membuat siswa berpikir sejenak. Keterampilan lisan yang kompleks menghasilkan ungkapan kebahasaan yang sistematis meliputi lafal, intonasi, dan pemilihan kata, beberapa aspek tersebut termasuk dalam aspek pragmatis bahasa. (Bailey (dalam Anggraini, 2016: 131); Nurgiyantoro, 2001: 289). Selain itu, aspek non kebahasaan yang harus dibangun dalam kegiatan menjawab pertanyaan ini adalah keberanian dan penguasaan tema. Apabila kegiatan ini dilakukan secara konsisten secara bergiliran, maka akan terdapat perkembangan signifikan pada tiap-tiap siswa sesuai dengan kompetensi yang mereka miliki.

\section{SIMPULAN}

Berdasarkan hasil penelitian teoritis, Buku Tematik Terpadu Kurikulum 2013 kelas 2 Tema 6 Merawat Hewan dan Tumbuhan dapat menjadi salah satu sumber atau media belajar yang mampu mengembangkan kecerdasan linguistik pada keterampilan berbicara.Hasil penelitian ini mengungkapkan metode dan teknik yang dapat dilakukan guru pada siswa SD kelas 2 dalam mengembangkan kecerdasan lingiuistik salah satunya dalam aspek berbicara dapat dilakukan dengan kegiatan, 1) membaca puisi, 2) bercerita, 3) bernyanyi, dan 4) menjawab pertanyaanKegiatan ini jika dilakukan secara konsisten secara bergiliran, maka akan terdapat 
perkembangan signifikan pada tiap-tiap siswa sesuai dengan kompetensi yang mereka miliki. selain itu, siswa akan mendapatkan pengalaman belajar yang bermakna jika mereka memperoleh pembelajaran langsung setelah melihat, melakukan dan merasakan.

\section{DAFTAR RUJUKAN}

Anggraini, Nur Farida. 2016. Peningkatan Keterampilan Bercerita Menggunakan Media Boneka Tangan. Jurnal Pendidikan Guru Sekolah Dasar. Edisi 17, Tahun ke 5. Hal. 629-640.

Cahyo N. Agus. 2013. Panduan Aplikasi Teori Belajar Mengajar. Jogyakarta.

Jamalus, 1998. Pengaaran Musik Melalui Pegalaman Musik. Jakarta: Depdikbud, Dirjen Dikti, PPLPTK.

Lahamando, Irfandi. tt. Peningkatan Hasil Belajar Materi Bernyanyi Melalui Metode Demonstrasi Siswa Kelas V SDN Rarampadende. Journal Kreatif Tadulako Online. Vol. 4, No.6.

Marlina, Elin., Apriliya, Seni dan Hamdu, Ghullam. 2018. Kemampuan Bercerita Siswa SD Menggunakan Buku Pop Up. PEDIDAKTIKA: Journal Ilmiah Pendidikan Guru Sekolah Dasar. Vol. 5, No.1. Hal. 84-99.

Nurgiyantoro, Burhan. 2001. Penilaian dalam Pengajaran Bahasa dan Sastra. astra. Yogyakarta:

Prayoga, Y.A. 2012. Kemampuan Bercerita Siswa Usia 7-8 Tahun Berdasarkan Klarifikasi Kalimat Bahasa Indonesia. Jurnal Skriptorium. Vol.1, No.2 Hal. 121-128.

Sanjaya. 2006. Pembelajaran Berbasis Kompetensi. Bandung: Kencana.

Sumaryanto. 2005. Pengembangan Instrumen Pengkuran Kemampuan Solfegio. Tesis tidak dipublikasikan. IKIP Jakarta.

Sinapati,. Syamsudiin,.dan Barasandji, Sahrudin. tt. Peningkatan Kemampuan Berbahasa Lisan Siswa Kelas IV SD Inpres Pandwangi Kecamatan Toili Barat Kabupaten Banggai Melalui Media Gambar Denah. Jurnal Kreatif Taulako Online. Vol. 5, No. 1.

Soleh, I. 2010. Pelatihan Membaca Puisi dan Cerpen untuk Sekolah Menangah. Jakarta: Pusat Bahasa Kemendiknas.

Yumnah, Siti. 2016. Kecerdasan Anak dalam Pengenalan Potensi Diri. Jurnal Studi Islam. Vol. 11, No. 2.

Zuchdi, Darmayanti dan Budiasih. 1997. Pendidikan Bahasa dan Sastra Indonesia di Kelas Rendah. Jakarta: Depdikbub RI. 